\title{
INDIGENOUS POLICING AND CRIMINAL JUSTICE ADMINISTRATION: A STUDY OF THE OKPOSI COMMUNITY IN OHAOZARA LOCAL GOVERNMENT AREA, EBONYI STATE, NIGERIA
}

\author{
Udo CHIKEZIE OSISIOGU - OKoRo PAUL MMAHI ${ }^{l}$
}

\begin{abstract}
This study explores autochthonous methods of policing and law enforcement in the community, and the perception of indigenes of the efficacy of these methods. Qualitative methods were adopted, involving the use of in-depth interview technique with indigenes: namely, members of a youth forum, community leaders, and elders. Findings show that offences in Okposi community may be classified into two types: abominations, and torts, while the indigenous crime prevention and control structure involves Ndi Uke (a community male elders' council), Unyom Okposi (a council of female elders), Ndi Okenye (village elders' council), and Ndi Okorobia (youths). Fear of the inevitability of spiritual consequences from the gods appears to be a good source of crime deterrence. Traditional methods of policing were deemed more effective in relation to crime control. It is recommended that the Nigerian police should continue to take advantage of cordial relationships with the community to enhance peace, security, and justice.
\end{abstract}

KEYWORDS: Traditional policing, criminal justice, theory, Okposi

\section{INTRODUCTION}

Crime and deviance are global phenomena. Not all members of society conform to societal norms or laws. Policing is therefore required to secure lives and property in communities (Reiner, 2010). Though securing lives and property is the function of the government, civilians may also play a significant

1 Udo Chikezie Osisiogu works at Nasarawa State University, Keffi, and Okoro Paul Mmahi at the

Federal University Gusau, Nigeria; e-mails: udosis@hotmail.com, paulokoro.m@gmail.com 
role in securing the community (Kasali - Odetola, 2016). Crime and deviance are prevented and controlled in varying ways in cultures around the world (Lambert, Jaishankar, Jiang, Pasupuleti, and Bhimarasetty, 2012). In England, during the early stages of societal development, the function of crime prevention and control was performed by members of various communities (Salter, 2014). According to Potter (2013), prior to the present formal method of policing there existed informal community-based policing (known as the "Watch"), in which volunteers were responsible for policing communities. During the precolonial period, Indian communities were also policed through informal indigenous methods (Lambert, et al 2012). In Africa, Baker (2008) affirmed the use of informal methods of crime control and sanctioning of offenders. In Nigeria, virtually all ethnic groups or communities still operate some form of traditional law enforcement and control.

Alemika (1993) observed that policing refers to coercive and ideological ways of regulating social life by the police and other state intelligence and security forces, as well as other methods put in place to inhibit behaviors that endanger social order. Violators of social norms are subjected to negative sanctions depending on the severity of the offence, and punishment/sanctions are meted out to those who violate norms (Little, 2013). This is done for the purpose of specific and general deterrence (Scharfer, 2002). Across communities, laws vary concerning who may be identified as an offender, the punishments that various offences attract, and how to restore damaged social relations (Cottino, 2008). According to Ordu - Nnam (2017), for the protection of lives and property behaviors considered harmful should be criminalized, and laws against such behaviors enforced.

Though the Nigerian police force is saddled with the constitutional power to secure the entire country, the importance of police collaborating with indigenous communities has culminated in the introduction of community policing. However, according to Gbenemene - Adishi (2017), little success has been recorded in this area due to the nature of the relationship between the police and members of the community, which is characterized by the distrust and unwillingness of police to share power with civilians. Nonetheless, indigenous communities retain informal methods of policing their communities. It is worthy of note that the introduction of a formal police force has reduced the extent of application of indigenous methods of policing. Some authors have noted that the prevention and control of crime across Nigeria by modern, government-based, law-enforcement agencies has not yielded the desired result, as the crime rate continues to rise (Ayuk - Emeka - Uyang, 2013).

Against this background, this study focuses on the indigenous approach to crime prevention and control in Okposi community. So far, studies on policing 
in Nigeria have focused on the informal policing strategies adopted by other ethnic groups, as well as informal policing in some Igbo communities, and the inadequacies of the Nigerian police force, and the nature of the relationship between the police and members of the public. The objective of this study was to examine the autochthonous method of policing peculiar to the Okposi community and the perception of community members about the effectiveness of autochthonous methods of policing in the community. The focus of the paper was informed by the failure of Nigerian police to adequately create security in relation to lives and property in the country (Ayuk - Emeka - Uyang, 2013), which has made local communities uphold and prefer their autochthonous policing methods.

\section{REVIEW OF LITERATURE}

\section{Historical Overview}

According to Ricken (2012), issues of local crime and security in traditional communities are addressed through the informal criminal justice system. Ricken (2012) added that informal methods of policing are popular on the one hand for being accessible, inexpensive, and quick. On the other hand, they may be criticized for being biased against women and other disadvantaged groups, and their noncompliance with international standards. For Melton (1995), outside the African continent the use of indigenous methods of policing endure alongside the modern system of criminal justice administration. Aiyedun - Odor (2016) observed that the introduction of English methods of policing notwithstanding, traditional African methods of enforcing justice still persist. In Elechi's (2006) study of the coexistence of African indigenous methods of justice administration and the justice administration system introduced by colonialists, it was noted that the two systems could be characterized by a duplication of functions and competition with each other. In comparing modern and traditional methods of crime prevention and control, Ayuk - Emeka - Iyang (2013) stated that despite the sophisticated equipment used by modern security agencies, the rate of crime in modern societies is higher than that of traditional societies in which crime is controlled without such sophistication.

In African traditional communities, crime is perceived as an abomination and consequently attracts severe consequences (Igbo - Ugwoke, 2013). With the advent of customary courts in Nigeria's judicial history, many traditional laws have been recorded over the years. However, in spite of the non-documentation 
of traditional laws, traditional laws that are not documented have been sustained and transmitted from generation to generation through oral traditional, and these laws nonetheless exert control over people's involvement in crime and deviant behavior (Genger, 2018; Okafor, 2006). However, Ebbe (2000) noted that colonialism and the consequent introduction of an English justice administration system have changed the prevailing customary order. Ebbe (2000) asserts that, as custodians of people's culture and the head of traditional institutions, it is the role of traditional rulers of each community in Nigeria to ensure that the norms of the community are not violated, and that those who violate them are sanctioned appropriately.

In Nigeria the police force has been mandated by the constitution to maintain law and order (Odisu, 2016).

\section{Examples from Nigerian Communities}

Abdulqadir (2016) stated that traditional rulers play a significant role in crime prevention and control across Nigerian communities. In Nigeria, one can find differing levels of confidence in traditional and community policing. For instance, Owumi - Ajayi (2013) found that due to the negative perception the Yorubas have about the police, people are advised to avoid mingling with them to forestall being assaulted. To buttress this point, Ajayi (2018) examined the indigenous methods of security maintenance in Ilogbo-Ekiti (a Yoruba community) and found that the community maintained the security of lives and property by enforcing norms through the imposition of sanctions ranging from ridicule, ostracism, excommunication, and death, depending on the offence committed. In this paper, the authors add that, with regard to capital punishment, only the state is empowered to carry out that sentence through the constitutional courts, but traditional societies rely on the judgment and discretion of deities to pass death sentences through unscientific or "spiritual" methods.

The findings of Idumwonyi - Ikhidero (2013), who studied the relevance of traditional policing in communities in Benin and in the Bini ethnic group in Nigeria, revealed that traditional methods which involve the use of the supernatural in crime control are preferred by members of communities due to the inadequacies of the modern system of policing. Zalanga (2018) noted that, with the high level of religiosity of Nigerians, Nigerians believe that the spiritual world controls the physical world. This is reflected in a study by Akubor (2016), who examined the use of masquerades in social control.

Akubor's (2016) findings showed that masquerades in various communities such as the Erinni (Elimin masquerades) among the Esan (a Benin Kingdom 
ethnic group located in Edo State, Nigeria) are believed to be organic to their myth of creation and operate as the major moderators of people's destiny. As far as individuals are concerned, the former are ancestral spirits who periodically visit their living forebears in masquerade forms. The Elimin are believed to possess power over life and death. Consequently, serious crimes are reported to them for adjudication and pronouncement of sentence, which may be severe, depending on the offence that is committed. According to Akubor (2016), another example can be found among the Ejagham society of Cross River State, whereby the task of detecting witches and wizards rests with the Echi-Obasinjom (the masquerade). Echi-Obasi-njom carries out this function through a wheeling, gliding dance that is organized by society.

Okoraforezeke (2003), in his study of traditional social control mechanisms in Igbo land, found that unofficial indigenous law enforcement apparatus employed by the people played a significant role in social control. According to Okoraforezeke (2003), those convicted of crimes against public morality are ostracized as a punishment to deter others from engaging in such acts, while the enforcement of norms is done by organs and groups of law enforcers created by the community. The Igbos, according to Aniche (2015), historically policed their communities using the age-grade system.

\section{THEORETICAL FRAMEWORK}

\section{Social Control Theory}

According to Jensen, (2003), this type of theory has its roots in perspectives about human society proposed by the English social philosopher Thomas Hobbes (1588-1679), who argued that human nature would create a perennial war of all against all were choices not constrained by inherent social contracts, agreements, and arrangements among people. Thus, such moral designations are created in the construction of social order which also assign costs and consequences to certain choices, while defining some as evil, immoral, or illegal (Jensen, 2003). Social control theory suggests that an individual's socialization and social learning process can be developed to build selfcontrol. This eventually lessens the tendency to engage in behavior regarded as antisocial (Osisiogu, 2013). Control theory starts with the assumption that the motivation for criminal behavior is a part of human nature, and that all individuals would naturally commit crimes if left to their own devices (Haskell - Yablonsky, 1978). 
Reiss (1951) argued that delinquency, for instance, was the result of a failure of personal and social control. Toby, in his explanation of behavioral control (1957), introduced the concept of having a "stake in conformity" as the basic mechanism by which tendencies toward delinquency are controlled. Nye's (1958) study focused on the family as the single most important source of social control for adolescents. For Reckless (1961), all individuals are affected by a variety of forces that drive them toward crime and delinquency, while a variety of other forces restrain them. Reckless (1961) called the driving forces "social control pressures." Sykes - Matza's (1957) study of delinquency noted that most of the time delinquents are engaged in routine law-abiding behavior, and that delinquents "age out" of delinquency when they reach late adolescence or early adulthood. The former also developed an analysis of "neutralization," a strategy adopted to rationalize deviant behavior.

Hirschi's (1969) social control theory posits that crime is a product of the weakening of bonds that connect people to society. According to Hirschi (1969), every individual is a potential law violator. What deters them from offending is the fear that violating a law would damage the relationship they have with family, friends, neighbors, colleagues, and community. Thus, the absence of social bonds predisposes people to commit illegal behavior. People become law violators when the bond they share with members of their religious, ethnic, racial, peer, and other groups become weak. Hirschi (1969) differentiated the bonds that people share with society into the following types: Attachment - this refers to a person's sensitivity and concern for others. For instance, for people's behavior to be controlled, resulting in abstinence from criminal behavior, they have to be attached to parents, peers, schools, work or community, to mention a few factors; Commitment - this refers to investing time, energy, and resources into acquiring an education, building a career, and growing business enterprises. Having invested a lot to succeed in these areas, individuals are less likely to get involved in acts that would endanger what they have toiled to build over the years, unlike those who have invested little or nothing; Involvement - people are detached from criminal activity if they are involved in legitimate or conventional activities such as business, school, religious, or any other social activity which leaves them with no time to consider committing a crime; and, Belief - which refers to shared belief in what is considered moral among members of a particular society or group. Values that are upheld in a society such as hard work, sharing, peace, abstinence from "evil," etc. are adhered to if they constitute the moral standards of that society. Those who engage in criminal or antisocial behaviors are those who lack such beliefs or those whose beliefs in the moral values of society are degraded. 
In Okposi community, members are socialized to abstain from behaviors that could subject their family to shame and ridicule. Those who are attached to family and friends do not violate social norms so as not to jeopardize the bond between them. In traditional societies like that of the Okposi, there is shared knowledge of each other's background. Being attached to family and upholding the "good name" of a family can deter individuals from engaging in behaviors that would result in the family being ridiculed. In the same vein, attachment to friends could result in conformity with social norms so as to avoid attracting the stigma associated with unacceptable behavior in traditional societies. It is the collective responsibility of all members of the Okposi community to ensure that the norms and values of people are protected.

\section{The Theory of Reintegrative Shaming}

This theory is relevant for understanding traditional methods of criminal justice. The major proponent of this theory, Braithwaite (1989), stated that societies have lower crime rates if they effectively communicate shame about crime. For instance, societies will have a lot of violence if violent behavior is not shameful, or high rates of rape if rape is something men can boast about, or widespread white-collar crime if business people think law-breaking is intelligent rather than shameful (Braithwaite, 1989). Distinguishing between reintegrative shaming and stigmatization, Braithwaite (1989) stated that the former discourages deviance by treating offenders as good people who have deviated from norms whose behavior should be corrected, while stigmatization treats offenders as bad people, leaving them with permanent stigma.

Braithwaite (1989) mentions an example of research that supports this theory that was produced by an Afghan criminologist at the University of Edinburgh, A. Ali Serisht. Serisht noted that the Pushtoon, the largest ethnic group in Afghanistan, have an institution called Nanante that is similar to the concept of conferencing. This involves a ceremony during which a criminal offender brings flour and other food and kills a sheep for a community feast. This feast is usually held at the victim's house, and the victim will participate in cooking the food the offender brings. The offender is reminded of their injustice and reminded that they are still a member of the community (Braithwaite, 1989). Also, it has been shown that American families that confront wrongdoing while sustaining relationships of love and respect for their children are the types of families most likely to raise law-abiding citizens (Braithwaite, 1989: 71-83). Makkai - Braithwaite's (1994) study on the enforcement philosophy of nursing home inspectors in Australia, the US, and UK suggests that inspectors are 
ineffective when they are tolerant and non-judgmental in the face of failures by nursing home management regarding meeting the standards of care for the elderly required by the law. Nursing home compliance with the law actually declines following inspections by tolerant and understanding inspectors.

\section{STUDY SETTING AND METHODS}

The study was conducted among indigenes of the Okposi community in the Ohaozara Local Government Area of Ebonyi State. Ebonyi State is one of the 36 states in the Federal Republic of Nigeria. Ohaozara has a total area of $312 \mathrm{~km}^{2}$ and, according to National Population Commission projections, had a population of 165,895 in 2010 (National Bureau of Statistics, 2013). The motto of Ebonyi State, Salt of the Nation, is derived from the salt lake located in the area. An exploratory research design and qualitative methods of data collection were adopted for the study. Data were elicited from indigenes of the community using in-depth interviews, through which respondents were engaged in face-toface interaction. Purposive and snowball sampling techniques were employed to select respondents. In the first instance, an elderly male community leader and a youth leader were approached in respect of the research, the purpose of which was explained to them. After giving consent to participating in the research, the elderly community leader directed the researchers to other community leaders who also participated. The community leaders in turn directed the researchers to other adults who have knowledge of indigenous policing and justice administration in the community. The inclusion criteria for the selection of respondents were: indigeneship (only indigenes were selected), and age (30 years old or older). The thirty-year benchmark was adopted to select out respondents who were knowledgeable about the objective of the study. A total of 122 respondents were interviewed, as follows: 15 youths, 31 community leaders, and 76 elders holding no leadership positions. Nine (9) research assistants assisted with data collection without an honorarium. Out of the 122 respondents, 92 were males, while 30 were females. All the respondents were engaged in farming. Thirty-nine respondents combined farming with artisanship, while 83 respondents combined farming with trade. Data were recorded using field notes and thereafter subjected to manual thematic analysis. Patterns within the data were organized according to the objectives of the study. To distinguish between respondents, a coding system was adopted in which respondents were assigned pseudonyms. To elicit information from the respondents, the interviews were guided by the following questions at the start of the interviews. 
i. What constitutes a criminal offence in traditional Okposi community?

ii. Who are the informal law enforcers in Okposi community?

iii. In which indigenous ways are violations of law dealt with?

iv. What is your perception about the efficacy of indigenous and formal methods of crime prevention and control?

v. To what extent do members of the community partner with the Nigerian police in dealing with offenders?

There were follow-up questions for each respondent based on the answers they provided. Prior to the interview, the purpose of the research was explained to the respondents and consent was received from each of them. No honorarium was given to participants or research assistants for participating in the research. Each interview session lasted for 45 minutes. Sample saturation was reached after the $122^{\text {nd }}$ person was interviewed. At that point, no new information was elicited, and sufficient data that addressed the objective of the study had been collected. Respondents were not subjected to stress as they were allowed to choose a time and venue conducive for them for the interview after informed consent was granted.

\section{FINDINGS AND DISCUSSION}

The findings of this study are divided into four sub-themes identified from respondents' responses: Indigenous prohibitions: 1) abomination (aruru ani) and torts (njo);2) indigenous structure in relation to social order; 3) community perception: juxtaposing autochthonous and formal crime prevention and control; and 4) involvement of the police. With reference to social control theory adopted in this study, findings fall into the second type of social control identified by Cragum and Cragum (2006), which is informal social control. To ensure social order in Okposi community, behaviors are controlled through norms and the enforcement of compliance with norms through indigenous structure. The community's methods of controlling deviant and criminal behaviors are discussed in sub-themes below.

\section{Indigenous prohibitions: Abomination and torts}

What constitutes an offence in Okposi community may be classified into two sub-groups: abomination (aruru ani), and torts (njo). Findings show that actions 
that are considered and treated as abominations and torts in Okposi are not in dissonance with the criminal laws of Nigeria. However, the autochthonous methods of treating offenders differ from those of the formal criminal justice system. In the study area, abominations are actions or behaviors that community members must avoid to forestall incurring the wrath of the gods, and avoid subjecting the entire community to attendant dire consequences. In Okposi community, abominations known as Aruru ani are serious offences against the land and collective morality and the existence of the entire community. Offenders are therefore deemed to have committed a crime against the entire community. Such offences include suicide, murder, manslaughter, incest, and adultery. The punishment for such offences may include death, to be carried out by the gods spiritually. The reliance of the community on gods to spiritually carry out this punishment is premised on the belief of the community that the gods are powerful and just; and also due to the constitution and laws of Nigeria, which empower only the formal criminal justice system to punish offenders. Banishment can also be pronounced traditionally and enforced through isolation or disassociation, but in reality it is difficult to enforce legally. Forms of closure include material compensation and public-apology ceremonies.

The following actions were identified by respondents as abominable and torts for the Okposi:

Homicide - Spilling of blood (which is sacred) is abhorred in Okposi community. The offence of willful murder is therefore punishable by death, inflicted by the gods of the land. Upon commission of the crime, the elders of the community unanimously place a curse on the offender, and collectively pronounce judgment upon him or her. This punishment is executed by the gods of the land, as it is expected that within one year of the time the crime was committed the offender will meet his or her death mysteriously. Furthermore, everyone who comes across the offender affirms the popular belief, saying to the offender, "may the consequence of your offence befall you." Within one year, the offender will encounter an occurrence that will result in his or her death. The offence of murder is a rarity in the Okposi community. For homicide committed by unknown person(s), the elders of the community unanimously place a curse on whoever committed the crime, and ask the gods to avenge the death of the deceased. Thereafter, the deceased is buried with a cutlass and is urged to use the cutlass against whoever was responsible for their death. With regard to this, an elderly respondent stated that:

Shedding of blood is an abomination and the gods of the land do not spare murderers. We believe in ometara vuru (anyone who gets involved in an evil act should meet their nemesis). Therefore, we hand the 
killer over to the gods of the land to avenge the death of the deceased. (Uka/M/IDI/Okposi)

Manslaughter - The offence of manslaughter is pardonable (within the community, but police involvement could involve state prosecution). The offender is usually mandated to bear all the cost of burying the deceased. Thereafter, the community makes peace between the families of the deceased and the offender to facilitate reconciliation and avoid retaliation. A respondent stated the following:

Taking a life is evil, and the killer cannot go unpunished. However, if the killing is unintentional, the offender would be asked to ensure that the deceased is given a befitting burial. He is the one that will pay all the bills. (Ako/M/IDI/Okposi)

Suicide - Members of the community believe that the actions and inactions of an individual have consequences that will be inflicted by the gods (and may be dire) on the entire community if not appropriately addressed. In relation to the offence of suicide, no member of the community is expected to take their own life, as this is considered an evil and forbidden act which could subject the community to an unpleasant aftermath. Therefore, anyone who commits suicide has committed a taboo against the community. In response, the community, in a bid to avert impending "evil occurrences," performs a ritual cleansing exercise to purify the defiled land, and the family of the deceased are made to bear the cost of cleansing the land. The deceased is not given a befitting burial. A respondent explained this approach, saying:

Suicide is evil. How can someone take his or her own life? If anyone does that, the community has to cleanse the land and his/her family must bear the cost. If ritual cleansing is not done, then tragedy becomes imminent. (Obodo/M/IDI/Okposi)

Incest and adultery - These offences are considered an abomination in Okposi land. Having sexual intercourse with a blood relation is an abomination. In the same vein, adultery is a forbidden act in this community. The punishment for incest and adultery is either shaming and ridicule or death. To avoid death inflicted by the gods, the offender must confess to the crime and afterwards be subjected to public shaming. Failure to confess to the crime attracts a strange sickness that may lead to the death of the offender. Such sicknesses are believed to be inflicted by the gods. For fear of incurring the wrath of the gods, those who 
commit such offences confess to the crime and face public shaming and ridicule. According to a respondent:

How could someone have sexual intercourse with someone related to him or her by blood? It is an abomination. In the same vein, adultery is a forbidden act in this community. The punishment for engaging in such acts is a strange sickness that will lead to the death of the person if he/she refuses to confess early. But if the person confesses on time, anybody that comes in contact with him/her will say to the offender "may the consequences of your action befall you." Then the gods take over. (Ogbo/M/IDI/Okposi)

Torts (njo) in the community are offences against the individual that attract the intervention of the community in the form of restorative justice. Torts attract sanctions that act as forms of specific and general deterrence. The community settles grievances and makes peace between the offender and the victim. These offences include stealing, assault, and malicious damage of property, among others. Punishments for torts include restitution, shaming, and fines. Respondents identified the following as torts in the community:

Stealing - The offence of stealing attracts restitution, fine, and shaming. The thief is paraded around the community with the stolen item. Afterwards, a fine is imposed on him or her for committing a shameful act. All this is in addition to the restitution of the stolen item, which is given back to the person from whom it was stolen. Okposi residents affirm that stealing is a shameful act, and it is against their norms and values. The parading of thieves is done to show the entire community that the offender is a thief, and this serves as a deterrent to community members. This is in consonance with Braithwaite's (1989) theory of reintegrative shaming, which holds that making certain acts shameful deters people from engaging in them. A respondent buttressed this claim, saying:

Stealing is a shameful act, and it is against our norms and values. If anyone steals, he/she must be paraded round the community with the stolen item to show the entire community that they are a thief. After that, they will replace the item they stole, and also pay a fine for engaging in such a shameful act. This will serve as a deterrent to them and others. (Nath/M/IDI/Okposi)

Similarly, Akuk, Emeka, and Uyang (2013) found that apprehended thieves in Odukpani Local Governments were made to face public shaming to serve as a deterrent to other would-be thieves. This was done by rubbing the offender with 
charcoal and parading them naked around the community. In the same vein, Ajayi (2018) found that subjecting violators of social norms to public disgrace and abhorrence culminated in a reduction in the rate of recidivism in IlogboEkiti.

Assault - Anyone who commits assault against another pays a fine as determined by the elders. The fine depends on the degree of assault and other circumstances surrounding the incident. In the case of physical injury, the offender bears the cost of treating the victim in hospital. However, if the assaulted person retaliates, and a fight ensues, both parties are liable to a fine as determined by the elders, and each person is asked to bear the cost of treating himself or herself for any resulting injury. An elder buttressed this approach, saying:

Assault attracts two punishments: a fine, and the cost of treating the assaulted person. The assaulted person must be given adequate medical treatment. If you say you do not have money to pay a fine and hospital bill, you have to sell your property to raise the money. (Chukwu/M/ IDI/Okposi)

Malicious damage - The punishment for willful destruction of another person's property is restitution within a specified period of time. Failure to replace the damaged property within the given time attracts an additional fine which must be paid in addition to restitution.

Destroying somebody's hard-earned property is an act of wickedness. The penalty for this is the payment of a fine and restitution. (Amara/F/ IDI/Okposi)

Defamation - The offence of character defamation is condemnable and offenders are made to restore a damaged reputation by making a public announcement while moving or walking through the four market squares or arenas on the four market days (Eke, Orie, Afor, and Nkwo). They ring a bell and proclaim that they have made false defamatory comments against the victim(s).

We do not tolerate defamation of character. One who defames another will be compelled to pay a fine and move around four markets, which represent the four market days, with a bell, proclaiming publicly that the defamed person is innocent of the defamatory comments made against them. (Nkume/M/IDI/Okposi) 


\section{Autochthonous approach to the prosecution of offenders}

The community has in place a decentralized jurisdictional structure to ensure social order and the prosecution of offenders. This is the council of male village elders (ndi okenye); the Ndi Uke (council of community male elders); the Unyom Okposi (council of selected female elders or Okposi wives drawn from the component villages); and the Village Youth Forum (ndi okorobia), each operating within their traditional areas or field or subject of jurisdiction. The structure of offender prosecution of the Okposi community is similar to that described in the findings of Onyeozili and Ebbe (2012) - namely, that precolonial Igbo societies ensure social order through the use of councils of elders, title-making associations, and age grades.

Village Youth Forum (ndi okorobia) - Each of the component villages has youth forums that perform the function of providing security for the village. This forum has the backing of the entire village, which also provides the necessary materials needed for policing the community. Their methods of operation involve patrolling the village at night to forestall criminal acts. They are usually divided into sub-groups who police the community on a rotational basis. While these sub-groups operate at night, daytime policing is collectively undertaken. The forum also apprehends and "tortures" criminals, and subsequently takes them to the council of elders for trial and pronouncement of an appropriate punishment. They can also perform stop-and-search operations at night in particular. It is important to note that the forums' rules and modus operandi take into consideration the rules and expectations of the Nigerian police. A respondent stated that:

Youth play a significant role in securing this community. They patrol the nooks and crannies of each village, especially at night, to ensure the security of lives and property. To me, they have contributed immensely to the security of this community. (Njoku/M/IDI/Okposi)

Council of village male elders: This is the highest decision-making body in each of the villages that makes up the community. Judgments are passed by this council in cases of abominations and torts at the village level. However, judgment passed by this council related to tort offences can be appealed by the offender if they deem such judgment to be unfair. In this case, the offender or accused person can resort to Ndi Uke at the community level for "final" judgment.

Ndi Uke (Council of community male elders): This is the highest-level decision-making body at the community level. Criminal and other cases beyond 
the resolution of village elders are referred to this body and their judgment is final. Membership of this body is based on proven integrity and members are drawn from each of the villages that make up the community. Each village is represented by two men who serve in that capacity for a lifetime. However, the membership of any member of this council who engages in any criminal or abominable act is terminated after trial and punishment. A member of the community affirmed that...

In Okposi community, the community's Ndi Uke is like the "Supreme Court of Nigeria" for Okposi people. Their judgment on any issue is final as far as Okposi community is concerned. Cases are referred to them only when they cannot be resolved at the village level. $(\mathrm{Mma} / \mathrm{F} /$ IDI/Okposi)

Unyom Okposi (Council of Okposi wives) - This council is composed of elderly married women of integrity, drawn from each of the component villages. Each member has or uses a staff (walking stick). They are invited to elicit a confession from accused persons or to validate statements from the accused. In doing this, they collect their staffs together and ask the accused person to climb the bundle of staffs and proclaim that their nemesis will catch up with them within one year if they are guilty of the crime they have been accused of. The nemesis could be death, sickness, or heavy loss, depending on the offence that has been committed. Due to the history of tragedies that have befallen individuals suspected of being guilty and who climbed the women's bundle of staffs and did not confess to their crimes, the Unyom Okposi can elicit a confession from suspects without subjecting them to torture. People know the consequences of lying when standing on those working sticks. The prescribed punishment is then applied to those who plead guilty, while those who plead not guilty are left to be punished or vindicated by the gods within a period of one year.

"Unwom Okposi" is a body that is resorted to when people commit a crime and deny it. The method of ascertaining guilt or innocence is simple. Just climb the pile of working sticks [staffs] and plead not guilty and see what will happen if you have actually committed a crime. People know the consequences of lying when standing on those working sticks. So, once you are invited to appear before them [the Council of Okposi wives], anybody that loves you would advise you to plead guilty of the offence if you have committed it. (Agadi/M/IDI/ Okposi) 
The foregoing indicates that, in traditional Okposi community, there is no room for torture as a means of extracting confession from accused persons. This contrasts with the activity of the formal police force, which uses physical torture to elicit confessions from suspected offenders. In this autochthonous method of confession extraction, offenders plead guilty not as a result of pain inflicted on them, but as a result of unavoidable repercussions.

\section{Involvement of the Police}

There is a general belief among members of the community that all cases can be handled by the community without resorting to the police. Therefore, the police are rarely involved in dealing with criminal and other cases in the community. Anyone who reports a case to the police without first exhausting informal mechanisms and securing the approval of the community would be asked to withdraw the case and is also liable to a fine. Only cases that are beyond settlement through the informal process of criminal justice administration are referred to the police. However, at present in Okposi community, murder cases are immediately referred to the police for formal investigation and prosecution.

In this community, victims of criminal or other offences are not expected to report them to the police without first exhausting the options available in the community. This is because we believe any offence can be settled within the community without necessarily involving the police. You can only involve the police if you are asked to do so by the either the village council of elders or the "Uke." But these days, if an unfortunate incident of murder occurs, it would be referred to the police to handle. (Agadi/M/IDI/Okposi)

\section{Community perception: Juxtaposing autochthonous and formal means of crime control}

The perception of a people about a phenomenon determines their disposition and action towards it (Mmahi - Usman 2019; Ulm 2018; Filteau 2012). Comparing the rate of crime in the past and present times, respondents maintained that indigenous means of crime prevention and control are more efficacious than formal, "alien" methods. According to them, the present formal means of justice administration is typified by the uncertainty of offender prosecution as a result of corruption, and 
the gross inadequacy of the presence of police, which make indigenous methods a preferred choice among members of the community. On the other hand, the traditional autochthonous system is characterized by inevitable consequences unleashed by the gods of the land. Behavior in the indigenous community is not only regulated by fear of punishment by the gods, but also the certainty of prosecution. Regarding the uncertainty of offender prosecution that characterizes the formal system, respondents explained that with the present process of justice administration, the ubiquity of crime in Nigeria today is traceable to the inadequate prosecution of offenders due to corruption (among other things), which, according to them, encourages crime. Corruption was explained as the use of financial or material inducement (given to prosecutors by offenders) to evade prosecution. This, the respondents averred, was a huge setback to the formal process of crime control. The gross inadequacy of a police presence was explained by reference to the lack of numerical strength of the police, as a result of which they are not available in virtually any of the villages in the community, except at the police station and near major roads. A respondent compared the incidence of crime at the time that traditional methods of social control were solely employed with the present time, when constitutional power is vested in the criminal justice system:

Crime was rare in the days we solely policed ourselves in our indigenous ways. Those were the days when we had no keys because there was no need for them. In those days, we left our doors open and went to the farm and nobody entered the house to steal anything. But now, people steal both at night and in the daytime. (Eke/F/IDI/Okposi)

Another respondent alluded to the factors that have militated against the efficacy of the formal justice system, which according to him are not typical of the autochthonous methods of crime prevention and control. He stated the following:

Our indigenous ways of ensuring a crime-free society are very effective. You can't compare them with those being applied by the government. With all the money that government is spending on the security agencies, crime is still ravaging the country. This tells you the system has failed. (Uga/M/IDI/Okposi)

Responding to a follow-up question about why he thinks the formal system has failed, the above respondent stated that the system is devoid of certitude with respect to the prosecution of offenders as people can influence the outcome of their trials in material ways. 


\section{CONCLUSIONS AND RECOMMENDATIONS}

This study has examined traditional methods of policing in Okposi, Ohaozara Local Government Area of Ebonyi State. The significance of cultural norms and values, especially as these concern deviant behavior and criminal activity, are similar to Durkheim's (1953) concept of collective conscience. The acts defined as criminal offences by members of Okposi community are in consonance with Nigerian criminal law. The study therefore concludes that indigenous methods of crime prevention and control are still useful in this contemporary society.

It is therefore recommended that formal law enforcement agencies should enhance their collaboration with such communities through effective community policing. Through this, the latter could adequately assist the police in preventing and controlling crime, and the police could ensure that offenders are treated in line with the provisions of criminal law. The positive aspects of shaming (reintegrative shaming) can be employed to encourage offender-familycommunity integration.

The study has revealed the autochthonous structure of dealing with offenders that has effectively controlled crime in the study area. Formal law enforcement agencies can synergize their efforts with the community for crime prevention and control. For instance, confession may be elicited from suspects through the use of unyom Okposi without inflicting bodily harm.

Studies could be conducted to find out the factors that have led to the community's belief that the gods are prosecutors of offenders, and what these gods are. Also, studies could be undertaken to ascertain the level of awareness of, and perceptions about the formal police force in relation to indigenous methods of crime control in the study area, which this study did not examine.

\section{REFERENCES}

Abdulqadir, U. A. (2016), "Traditional rulers and security administration in Nigeria: Challenges for the 21st century", Journal of Humanities and Social Science Vol.21, No. 8, pp. 1-11. DOI: 10.9790/0837-2108060111

Adebisi, A.S. -Babajide, A. (2018), "African traditional method of social control mechanism: A sociological review of native charms in farm security in Ayetoro Community, Ogun State, Nigeria", International Journal of Humanities and Social Sciences, Vol.12, No. 4, pp. 507-511. DOI: 10.5281/zenodo.1316315 
Aiyedun, A. - Ordor, A. (2016), "Integrating the traditional with the contemporary in dispute resolution in Africa", Law, Democracy and Development, Vol. 20, pp. 155-173. DOI: 10.4314/ldd.v20i1.8

Ajayi, O. J. (2018), "Primordial patterns of security and social control system in Ilogbo Ekiti, Nigeria", Humanities and Social Sciences, Vol. 6, No. 3, pp. 88-96. DOI: $10.11648 /$ j.hss.20180603.11

Akubor, E. O. (2016), "Africans concept of masquerades and their role in societal control and stability: Some notes on the Esan people of southern Nigeria", Asian \& African Studies Vol. 25, No. 1, pp. 32-50.

Alemika E.E.O. (1993), "Colonialism, state and policing in Nigeria", Crime, Law and Social Change, Vol. 20, pp. 187-219. DOI: 10.1007/BF01308450

Aniche, E. (2015), "Community policing in the traditional Igbo Society: A model for preventing crime in the contemporary Nigerian society", SSRN Electronic Journal doi 10.2139/ssrn.2709434. Retrieved March 03, 2019

Ayuk, A. A. - Emeka, J. O. - Uyang, F.A. (2013), "Traditional methods of crime control and community security in Odukpani Local Government Area of Cross River State, Nigeria", Journal of Humanities and Social Science, Vol. 14, No. 5, pp. 61-66.

Braithwaite, J. (1989), Crime. Shame and Reintegration, Melbourne: Cambridge University Press.

Cottino, A. (2008), "Crime prevention and control: Western beliefs vs. traditional legal practices", International Review of the Red Cross, Vol. 90, No. 870, pp. 289-301.

Cragun, R. T. - Cragun, D. (2006). Introduction to Sociology, Wikibooks Edition $1.0,6^{\text {th }} \quad$ March. http://en.wikibooks.org/wiki/Introduction_to_Sociology Accessed Jan10, 2013

Durkheim, E. (1897/1951), Suicide: A Study in sociology, New York: The Free Press.

Durkheim, E. (1953), Sociology and philosophy. New York: The Free Press.

Ebbe, O. N. I. (2000), "The unique and comparative features of criminal justice systems: Policing, judiciary and corrections", In O. N. I. Ebbe ed. Comparative and international criminal justice systems: Policing, judiciary and corrections. $2^{\text {nd }}$ Edition, Boston: Butterworth-Heinemann, pp 277-89.

Elechi, O. O. (2006), Doing Justice without the State: The Afikpo (Ehugbo) Nigeria Model, New York: Routledge

Filteau, M.R. (2012), “Deterring defiance: 'Don't give a poacher a reason to poach”” International Journal of Rural Criminology Vol. 1, No. 2, pp. 236-55. DOI: $10.18061 / 1811 / 53696$

Gbenemene, K. - Adishi, E. (2017), “Community policing in Nigeria: Challenges and prospects", International Journal of Social Sciences and Management Research, Vol 3., No. 3, pp. 47-53. 
Genger, P. (2018), "Combating corruption with African restorative justice tradition: Suggested steps for Nigeria", African Journal of Criminology and Justice Studies, Vol. 11, No. 1, pp. 20-40.

Gibbs, J. P. (1989), Control: sociology's central notion, Urbana: University of Illinois Press

Hannem-Kish, S. (2004), "Crime, shame, and reintegration”, in: Encyclopedia of Prisons \& Correctional Facilities, Thousand Oaks: Sage

Haskell, M. R. - Yablonsky, L. (1978), Crime and Delinquency, Third Edition, Chicago IL: Rand McNally \& Co.

Hirschi, T. (1969), Causes of Delinquency, Berkeley: University of California Press Idumwonyia, I. M. - Ikhiderob, S. I. (2013), "Resurgence of the traditional justice system in postcolonial Benin (Nigeria) Society", African Journal of Legal Studies, Vol. 6, pp. 123-135. DOI: 10.1163/17087384-12342017

Igbo, U. M. E. - Ugwuoke, O. C. (2013), "Crime and crime control in traditional Igbo society of Nigeria”, Developing Countries Studies Vol. 3, No. 3, pp. 160-167.

Jensen, G.F. (2003), “Social Control Theories”, In: R. A. Wright ed. Encyclopedia of Criminology, Fitzory Dearborn Publishers

Kasali, M. A. - Odetola, R. G. (2016). Alternative approach to policing in Nigeria: Analyzing the need to redefine community policing in tackling the Nation's security challenges, African Journal of Criminology and Justice Studies, Vol. 9, No. 1, pp. 98-115.

Lambert, E.G. - Jaishankar, K. - Jiang, S. - Pasupuleti, S. - Bhimarasetty, J.V. (2012), "Correlates of formal and informal social control on crime prevention: An exploratory study among university students, AndhraPradesh, India", Asian Criminology, Vol. 7, pp. 239-250. DOI: 10.1007/s11417-011-9108-9

Makkai, T. - Braithwaite, J. (1994), "Reintegrative shaming and compliance with regulatory standards", Criminology Vol. 32, pp. 361-385. DOI: 10.1111/ j.1745-9125.1994.tb01158.x

Melton, A. P. (1995), "Indigenous justice systems and tribal society" Judicature, Vol. 79, No. 3, pp. 126- 133.

Mmahi, O.P. - Usman, A. (2019), "Hunting is our heritage; We commit no offence: Kainji National Park wildlife poacher, Kaiama, Kwara State Nigeria", Deviant Behavior doi: 10.1080/01639625.2019.1629537

Nye, F. I. (1958), Family relationships and delinquent behavior, New York: John Wiley.

Odisu, T.A. (2016), "Law enforcement in Nigeria by the Police Force and the travails of rule of Law", Journal of Civil Legal Sciences Vol. 5, No. $5,204$. 
Okereafoezeke, N. (2003), "Traditional social control in an ethnic society: Law enforcement in a Nigerian community", Police Practice and Research, Vol. 4, No. 1, pp. 21-33.

Onyima, B. N. (2015), "Traditional methods of social control in Afikpo North Local Government Area, Ebonyi State south eastern Nigeria", Journal of Religion and Human Relations, Vol. 7, No. 2, pp. 59-109.

Osisiogu, U.C. (2013), "The predictive ability of social control theory in explaining violence", Sokoto Journal of the Social Sciences, Vol. 31, No. 1, pp. 1-15.

Ordu, G. E. - Nnam, M. U. (2017), "Community Policing in Nigeria: A Critical Analysis of Current Developments", International Journal of Criminal Justice Sciences, Vol. 12, No. 1, pp. 83-97. DOI: 110.5281/zenodo.345716

Owumi, B. - Ajayi, J. O. (2013), "Traditional values, beliefs and reliance on indigenous resources for Crime Control in Modern Southwest Nigeria", African Research Review: An Interdisciplinary Journal, Vol. 7, No. 1, pp. 7394. DOI: $10.4314 /$ afrrev.v7i1.6

Potter, G. (2013), The history of policing in the United State, part 1. Retrieved from https://plsonline.eku.edu/insidelook/history-policing-united-statespart-1

Reiss, A. (1951), "Delinquency as the Failure of Personal and Social Controls", American Sociological Review Vol. 16, pp. 196-207. DOI: 10.2307/2087693

Reckless, W. C. (1961), The crime problem, New York: Appleton-CenturyCrofts.

Reiner, R. (2010), The politics of the police $4^{\text {th }}$ Edition. Oxford: Oxford University Press.

Ricken, J. (2012), The rule of law and informal justice systems: A potential conflict in judicial development. Oslo: UNDP.

Salter G. (2014), “Early Modern Police and Policing”, In: Bruinsma G., Weisburd D. eds., Encyclopedia of Criminology and Criminal Justice, Springer, New York, NY

Schaefer, R. T. (2002), Sociology: A brief introduction, New York: McGraw Hill Inc.

Sykes, G. M. - Matza, D. (1957), "Techniques of neutralization: A theory of delinquency”, American Sociological Review Vol. 22, No. 6, pp. 664-70. DOI: 10.2307/2089195

Sherman, L. W. (1993), "Defiance, deterrence and irrelevance: A theory of the criminal sanction", Journal of Research in Crime and Delinquency, Vol. 30, pp. 445-73. DOI: 10.1177/0022427893030004006

Toby, J. (1957), "Social Disorganization and Stake in Conformity", Journal Criminal Law \& Criminology Vol. 48, pp. 12-17. DOI: 10.2307/1140161 
Uhm, van, D.P. (2018), “The social construction of value of life: a green cultural criminological perspective", Theoretical Criminology Vol. 22, No. 3, pp. 384401. DOI: $10.1177 / 1362480618787170$

Zalanga, S. I. (2018), "Civil Society in Africa: Interrogating the Role of Pentecostal Christianity in Africa's Democratization and Development Process". In Kieh, G. K. Jr ed. Contemporary Issues in African Society: Historical Analysis and Perspectives, New York: Palgrave Macmillan 